DOI: https://doi.org/10.31933/jemsi.v2i6

Received: 29 Mei 2021, Revised: 19 Juni 2021, Publish: 23 Juli 2021

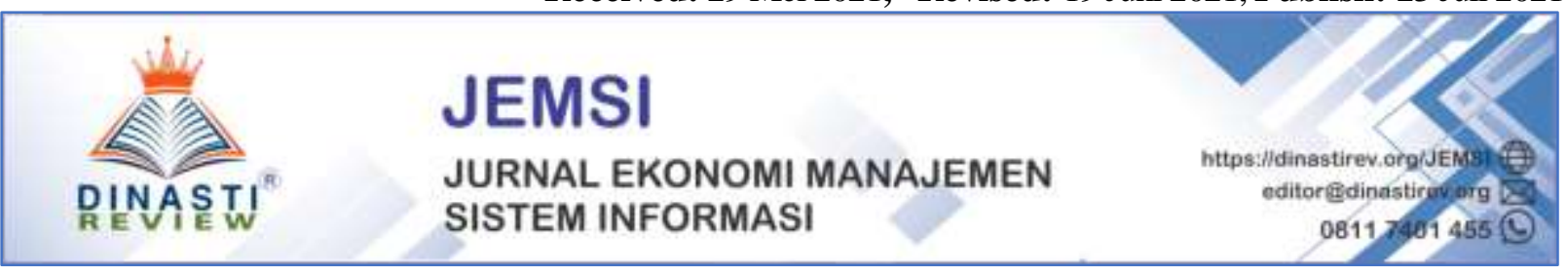

\title{
PENGARUH THE BIG FIVE MODEL PERSONALITY TERHADAP KINERJA PEGAWAI PADA KANTOR DINAS PENDIDIKAN KABUPATEN MAPPI
}

\section{Wilhelmus Antonius Djula ${ }^{1}$ \\ ${ }^{1}$ Mahasiswa Program Magister Manajemen Universitas Terbuka, antonius.djula@gmail.com}

\section{Korespondensi Penulis: Wilhelmus Antonius Djula}

\begin{abstract}
Abstrak: Penelitian ini bertujuan untuk mendapatkan gambaran mengenai pengaruh The Big Five Model Personality yang terbagi dalam lima dimensi dan akan dijadikan variabel dalam penelitian ini yaitu: Neouriticsm (X1), Extraversion (X2), Openness to experience (X3), Agreeableness (X4) dan Conscienctousness (X5) terhadap Kinerja pegawai (Y) di Kantor Dinas Pendidikan Kabupaten Mappi. Penelitian ini memiliki enam variabel yaitu 5 variabel bebas (X) dan satu variabel terikat (Y). Tujuan lain jurnal ini adalah untuk menjawab rumusan masalah yang diajukan dalam penelitian ini yaitu: (a) Apakah Neouriticsm (Ketidakstabilan emosi) berpengaruh terhadap kinerja pegawai, (b) Apakah extraversion (Keterbukaan) berpengaruh terhadap kinerja pegawai, (c) Apakah openness to experience (Keterbukaan terhadap pengalaman) berpengaruh terhadap kinerja pegawai. (d) Apakah agreeableness (Keramahan) berpengaruh terhadap kinerja pegawai, dan (e) Apakah conscienctousness (Ketelitian) berpengaruh terhadap kinerja pegawai. Manfaat yang didapatkan dari penelitian ini adalah memberi masukan dan informasi tambahan yang berarti untuk organisasi, perusahaan dan penelitian lebih lanjut mengenai teori keperibadian dan kinerja pegawai sebagai referensi untuk penelitian selanjutnya.
\end{abstract}

Kata Kunci: Five Model Personality: Neouriticsm, Extraversion, Openness to experience, Agreeableness, Conscienctousness dan Kinerja pegawai.

\section{PENDAHULUAN}

\section{Latar Belakang Masalah}

Sumber daya manusia dalam sebuah organisasi sangat mempengaruhi jalannya organisasi tersebut. Maka dari itu sumber daya manusia yang berkualitas akan menentukan keberhasilan suatu organisasi. Sumber daya manusia kini makin berperan besar bagi kesuksesan suatu organisasi. Banyak organisasi yang menyadari keunggulan bersaing. Mereka membuat sasaran, strategi, inovasi, dan mencapai tujuan organisasi. Oleh karena itu, sumber daya manusia merupakan salah satu unsur yang paling penting bagi organisasi (Rachmawati, 2008:1).

Manajemen sebagai ilmu dan seni mengatur proses pemanfaatan sumber daya manusia dan sumber-sumber lainnya secara efektif dan efisien untuk mencapai suatu tujuan tertentu (Hasibuan, 
2013:2). Sedangkan menurut Follet manajemen adalah seni untuk menyelesaikan pekerjaan melalui orang lain. Manajemen memiliki fungsi-fungsi seperti perencanaan (penetapan apa yang akan dilakukan), pengorganisasian (perancangan dan penugasan kelompok kerja), penyusunan personalia (penarikan, seleksi, pengembangan, pemberian kompensasi dan penilaian prestasi kerja), pengarahan dan pengawasan. Penerapan manajemen tersebut diterapkan dalam berbagai macam organisasi, yaitu organisasi sektor private (swasta/bisnis), organisasi sektor publik (birokrasi pemerintah), organisasi sosial maupun organisasi internasional (Handoko, 2014:3).

Pegawai yang baik akan senang menghadapi tantangan dan cenderung memiliki tanggung jawab bahkan tidak mudah putus asa, pegawai yang seperti ini akan selalu menyesuaikan dirinya agar terus mengalami perubahan dalam kinerjanya. (Ulandari, 2018:2). Sebuah instansi pemerintahan, pelayanan publik yang baik dan profesional sangat dibutuhkan, hal tersebut dipengaruhi salah satunya oleh pegawai yang bekerja di instansi tersebut. Kinerja sumber daya manusia yang baik merupakan hal yang terpenting bagi kelangsungan hidup organisasi. Sebuah organisasi yang ingin berkembang dengan pesat, harus memiliki sumber daya manusia yang mampu menampilkan kinerja yang baik. Kinerja pegawai yang baik merupakan harapan untuk instansi, berhasil atau tidaknya suatu instansi di lihat dari kinerja pegawai tersebut dalam melaksanakan tugas yang telah di tetapkan.

Salah satu masalah yang sering dihadapi organisasi berhubungan dengan kinerja diantaranya adalah pada hasil kerja pegawai, kinerja pegawai bisa menjadi tolak ukur suatu instansi. Tingkat kinerja seorang pegawai dipengaruhi oleh beberapa faktor yaitu kepemimpinan, budaya organisasi, motivasi, kompensasi dan keperibadian pegawai itu sendiri.

Kepribadian merupakan karakteristik seseorang yang menyebabkan munculnya konsistensi perasaan, pemikiran, dan perilaku. Definisi yang luas ini memungkinkan untuk fokus pada banyak aspek dari seseorang. Pada saat yang sama, definisi tersebut mengisyaratkan bahwa pola konsisten perilaku dan kualitas dalam diri seseorang, yang berbeda dengan misalnya kualitas lingkungan yang mempengaruhi kepribadian seseorang (Pervin, 2004:6). Menurut Burger kepribadian adalah pola perilaku yang konsisten dan proses interpersonal yang terjadi dalam diri individu. Sedangkan menurut Feist dan Feist kepribadian didefinisikan sebagai pola watak yang relatif permanen dan karakter yang unik dimana keduanya memiliki konsistensi dan keunikan pada perilaku individu (Saifha dan Supriyadi, 2013:74).

Penelitian yang dilakukan oleh Hogan adalah menghubungkan antara kepribadian dengan kinerja, hasilnya adalah bahwa secara garis besar sangat berarti. Rangkaian yang lebih tinggi tingkatannya menggambarkan kepribadian secara unik sebagai instrumen yang terstandar, yang memprediksi hubungan dengan pendekatan kinerja. Beberapa kasus mengutamakan pada kemampuan kognisi, khususnya dalam penelitian kepribadian hubungannya dengan model Lima Faktor Kepribadian yang sering disebut dengan "Lima Besar" (Widhiastuti, 2011:3). Goldberg mengemukakan bahwa "Faktor "Lima Besar" menjadi faktor eksistensi. Kata "Besar" maksudnya 
merujuk kepada temuan bahwa tiap faktor menggolongkan banyak sifat tertentu dalam hirarki kepribadian, faktor-faktor tersebut hampir seluas dan seabstrak Eyenck (Pervin, 2004:263).

Kinerja di tentukan oleh beberapa faktor diantaranya faktor lingkungan dan faktor personal kepribadian. Menurut Robbins (1996), kepribadian big five Kinerja ditentukan oleh beberapa faktor diantaranya adalah beban kerja dan kepribadian the big five personality, dimensi kepribadian tersebut antara lain (Robbins, 1998:55) kemantapan emosional (neouriticsm), ekstraversi (extraversion), keterbukaan terhadap pengalaman (openness to experience), mampu bersepakat (agreeableness), mendengarkan kata hati (conscienctousness).

Artikel ini khusus membahas The Big Five Model Personality yang dibagi dalam lima dimensi yaitu neouriticsm (X1), extraversion (X2), openness to experience (X3), agreeableness (X4) dan conscienctousness (X5) yang mempengaruhi Kinerja Pegawai (Y) di Dinas Pendidikan Kabupaten Mappi. Tentu tidak semua faktor yang mempengaruhi Kinerja Pegawai pada artikel ini. Ini hanya sebagian kecil saja yang akan dikaji dan di review.

\section{Rumusan Masalah}

Berdasarkan latar belakang masalah diatas aka dirimuskan masalah yang akan dibahas pada artikel literature riview agar lebih fokus pada kajian pustaka dan pembahasan, yaitu:
a. Apakah neouriticsm berpengaruh terhadap kinerja pegawai.
b. Apakah extraversion berpengaruh terhadap kinerja pegawai
c. Apakah openness to experience berpengaruh terhadap kinerja pegawai.
d. Apakah agreeableness berpengaruh terhadap kinerja pegawai
e. Apakah conscienctousness berpengaruh terhadap kinerja pegawai.

\section{Tujuan Penelitian}

Berdasarkan rumusan msalah diatas, dapat dirumuskan tujuan dari penelitian ini yaitu:
a. Untuk mengetahui pengaruh neouriticsm terhadap kinerja pegawai.
b. Untuk mengetahui pengaruh extraversion terhadap kinerja pegawai
c. Untuk mengetahui pengaruh openness to experience terhadap kinerja pegawai.
d. Untuk mengetahui pengaruh agreeableness terhadap kinerja pegawai.
e. Untuk mengetahui pengaruh conscienctousness terhadap kinerja pegawai.

\section{KAJIAN PUSTAKA}

\section{The Big Five Model Personality}

Kepribadian meliputi beberapa karakteristik yang membuat seseorang menjadi unik (Joseph, 2011). Berbagai dimensi dapat digunakan untuk mempelajari dan mengevaluasi kepribadian, tetapi satu hal yang menjadi kesepakatan dari beberapa penelitian tersebut adalah bahwa tidak ada dua individu yang benar-benar identik.

Tommasel et al. (2015:814) menjelaskan kepribadian sebagai salah satu faktor utama yang mempengaruhi perilaku manusia yang dilihat dari interaksi dengan orang lain. Menurut Montolalu 
et al. (2016:1320) berpendapat bahwa kepribadian sebagai gambaran dari seorang individu yang dilihat dari cara berfikir, berperilaku, berprasangka dan berinteraksi dengan orang lain.

John dan Srivastava (1999:6) mengelompokkan kepribadian menjadi lima dimensi diantaranya sebagai berikut:

a. Ketidakstabilan emosi (Neuroticism)

Pribadi neuroticism dikelompokan menjadi dua golongan, yaitu skor tinggi (reactive) dan skor rendah (resilien). Golongan dengan skor tinggi, memiliki kekhawatiran yang tinggi dan menunjukkan sikap yang cenderung mudah gugup dalam menghadapi masalah yang bersifat mengkhawatiran. Mereka mudah marah dan kurang percaya diri serta tidak mampu mengendalikan dorongan terhadap suatu keinginan yang dimiliki. Berbanding terbalik dengan golongan dengan skor rendah yang akan menunjukkan sikap yang tidak mudah khawatir dan memiliki sikap yang tenang terutama ketika menghadapi suatu stimulus yang dilihat sangat mengkhawatirkan. Golongan dengan skor rendah tidak mudah marah dan tergoda, sehingga mudah dalam mengendalaikan keinginan (Ghufron \& Risnawati S, 2010:137).

Karakteristik dari kepribadian ini meliputi: (1) Memiliki kecemasan (Anxiety) yaitu rasa khawatir, takut, gelisah, tegang dan gugup. (2) Memiliki amarah (Angry Hostility) menunjukkan kecenderungan untuk marah, frustasi dan rasa benci. (3) Merasa rendah diri atau tidak berharga (Depression) yaitu kecenderungan untuk mengalami depresi. (4) Kesadaran diri (Self-consciousness) yaitu bentuk emosi malu dan perasaan sungkan. Individu dengan self-consciousness yang tinggi akan timbul perasaan sungkan berada di antara orang lain, peka terhadap ejekan, dan mudah merasa rendah diri. (5) Menuruti kata hati (Impulsiveness) yaitu ketidakmampuan untuk mengontrol keinginan dan kepentingannya. Kesenangan (seperti makan, rokok, memilih barang) dirasakan sebagai sesuatu yang sangat kuat yang tidak bisa diredakan, meskipun dikemudian timbul rasa penyesalan. (6) Mudah tersinggung (Vulnerability) yaitu kemudahan seseorang untuk mengalami stres, menggambarkan perasaan tidak mampu melakukan coping stress, menjadi dependen, mudah putus asa, atau panik dalam situasi darurat.

b. Keterbukaan (Extraversion)

Pribadi extraversion merupakan pribadi yang berhubungan dengan perilaku individu, khususnya dalam hal kemampuan individu menjalin hubungan dengan orang lain. Individu dengan pribadi extraversion menunjukkan sikapnya melalui perilakunya yang memiliki kehangatan, suka berkumpul, memiliki ketegasan dalam hidup, memiliki level aktifitas, mencari kesenangan dan memiliki emosi yang positif. Individu yang memiliki extraversion akan cenderung memiliki kepribadian yang tegas dalam mengambil keputusan serta tidak enggan untuk menempatkan dirinya dalam posisi kepemimpinan (Ghufron \& Risnawati, 2010:137). 
Karakteristik dari kepribadian ini meliputi: (1) Memiliki kehangatan (Warmth) merupakan sisi traits kepribadian extraversion yang berhubungan dengan interaksi sosial dan sosiabilitas. (2) Suka berkumpul (Gregariousness) merupakan sisi kesukaan individu untuk bergabung dengan orang lain. Individu dengan gregariousness yang rendah diartikan sebagai individu yang menyukai kesendirian dan menyukai stimulasi sosial. (3) Memiliki ketegasan (Assertiveness) yaitu dapat dilihat dengan adanya dominasi, kekuatan yang tinggi, serta adanya asertivitas. Individu dengan traist kepribadian ini berbicara tanpa ragu-ragu dan lebih sering menjadi ketua kelompok. (4) Memiliki level aktivitas (Activity level) yakni dipandang sebagai individu yang mempunyai gerakan cepat, penuh semangat, dan menyukai kesibukan. Aktivitas yang rendah menunjukkan memiliki tempo yang lebih santai dan relaks, meskipun mereka tidak malas. (5) Mencari kesenangan (Excitement-Seeking) menunjukkan bahwa individu sangat menyukai dan membutuhkan stimulasi kegembiraan. (6) Memiliki emosi yang positif (Positive Emotions) yakni kecenderungan untuk mencari emosi positif, seperti kegembiraan dan kebahagiaan. Individu yang memiliki nilai tinggi pada fase ini menandakan individu yang mudah dan sering tertawa, gembira dan optimistik.

c. Keterbukaan terhadap pengalaman (Openness to experience)

Pribadi openness to experience menjelaskan tentang seberapa besar individu tertarik terhadap bidang tertentu secara luas. Sifat ini dibagi menjadi dua golongan, yaitu preserver (level rendah) dan explorer (level tinggi). McCrae dan John menerangkan bahwa individu dengan level rendah akan cenderung lebih fokus pada hal-hal yang sedang terjadi. Mereka memilih keterbatasan ide dan bersifat kaku dalam melihat nolai-nilai kehidupan. Sebaliknya, individu dengan level tinggi menunjukkan sikap yang imajinatif dan suka berangan-angan. Pada umumnya, individu dengan level tinggi memiliki kemauan yang tinggi untuk menciptakan minat yang lebih luas terhadap segala aspek kehidupan (Ghufron \& Risnawita S, 2010:139-140).

Karakteristik kepribadian ini yaitu: (1) Memiliki khayalan yang berlebihan (Fantacy) yakni kesukaan untuk berfantasi, berkhayal, bukan sebagai pelarian, tetapi sebagai cara bagi dirinya untuk memperhatikan innerworld. Mereka cenderung menjelaskan, menjabarkan, dan mengembangkan fantasinya dan percaya bahwa imaginasi memberikan kontribusi bagi kekayaan dan kreativitas kehidupan. (2) Keindahan (Aesthetics) menunjukkan minat yang tinggi pada seni dan keindahan. Mereka cenderung menyukai puisi dan musik meskipun tidak perlu menjadi seorang artis. (3) Memiliki perasaan yang sensitif (Feelings) mencerminkan keterbukaan pada perasaan yang dialami dan evaluasi terhadap emosi sebagai bagian yang penting dalam kehidupan. Bila faset ini rendah dalam diri individu maka menunjukkan bahwa individu tidak peduli pada perasaan yang dialami dan tidak percaya bahwa perasaan-perasaan yang dialami mempunyai arti yang dalam dan berarti penting.

\section{d. Keramahan (Agreeableness)}


Pribadi agreeableness diibaratkan sebagai perilaku prososial yang didalamnya termasuk perilaku yang selalu berorientasi pada penuh kepercayaan, suka berterus terang, mementingkan kepentingan orang lain, memiliki kepatuhan, memiliki sifat rendah hati, dan berhati lembut. Terdapat dua golongan dalam pribadi agreeableness, yaitu skor tinggi (adapter) dan skor rendah (challenger). Golongan dengan skor tinggi selalu memandang individu lain sebagai seseorang yang jujur, dan memiliki niatan baik kepadanya. Sebaliknya, golongan dengan skor rendah, akan memandang orang lain dengan perasaan ragu-ragu, curiga dan cenderung sinis (Ghufron \& Risnawati S, 2010:137).

Karakteristik dari kepribadian ini meliputi: (1) Memiliki kepercayaan (Trust). Skor yang tinggi pada faset ini menunjukkan individu memiliki disposisi untuk percaya bahwa orang lain memiliki kejujuran dan berniat baik pada dirinya. Bila faset ini rendah berarti ada kecenderungan bersikap sinis dan skeptis, dan mempuyai pikiran bahwa orang lain tidak memiliki kejujuran atau berbahaya bagi dirinya. (2) Suka berterus terang (Straighforwardness) menunjukkan bahwa individu cenderung terus terang. Skor yang tinggi menunjukkan kecenderungan individu untuk jujur, tulus hati, sederhana dan berterus terang. (3) Mementingkan kepentingan orang lain (Altruism) yang menunjukkan memiliki perhatian yang besar pada orang lain, memiliki kesediaan untuk membantu orang yang membutuhkan pertolongan, sedangan skor rendah menggambarkan adanya self-centered dan kurang peduli pada permasalahan yang dihadapi orang lain. Memiliki kepatuhan (Compliance) menunjukkan jika memiliki nilai tinggi pada faset ini berarti meliputi reaksi terhadap konflik interpersonal. Bila faset ini rendah berarti adanya kecenderungan agresivitas, tidak bisa bekerjasama, tidak enggan mengekspresikan kemarahan pada orang lain. (5) Memiliki sifat rendah hati (Modesty). Skala ini menggambarkan rasa rendah hati dan cenderung melupakan diri sendiri namun bukan berarti kurang percaya diri. (6) Berhati lembut (Tender-Mindedness). Mengukur sifat simpati dan perhatian pada orang lain. TenderMindedness yang tinggi menggambarkan adanya kebutuhan akan adanya keberadaan orang lain dan tumbuhnya rasa kemanusiaan, sedangkan skor yang rendah menunjukkan keras kepala dan tidak tergerak untuk bersikap kasih sayang pada orang lain.

\section{e. Ketelitian (Conscientiousness)}

Pribadi conscientiousness menunjukkan sejauh mana individu memiliki sikap yang hatihati dalam mencapai tujuan tertentu dalam sikap dan perilaku mereka. Pribadi conscientiousness dikelompokan menjadi dua, yaitu flexibel person (level rendah) dan focused person (level tinggi). Flexibel person menunjukkan sikap individu yang selalu merasa tidak siap dalam segala hal. Mereka cenderung menunda-nunda pekerjaan serta sering menunjukkan kebingungan dalam menjalankan tugas. Berbeda dengan focused person, menggambarkan sikap merasa mampu dalam melakukan segala sesuatu secara efektif. Individu dengan pribadi conscientiousness lebih fokus dengan segala tindakan dalam menyelesaikan tugas yang diterima. Pribadi conscientiousness sering diterapkan pada 
individu dalam dunia kerja yang menunjukkan sejauh mana individu dalam menggapai prestasi, bertanggung jawab, dan mempunyai kesungguhan hati serta kerja keras (Ghufron \& Risnawita S, 2010:138).

Karakteristik dari kepribadian ini meliputi: (1) Memiliki kompetensi (Competence) yang mengungkap suatu keyakinan pada dirinya, perasaan mampu, berpikir sehat, bijaksanaan, dan efektif. Bila skor ada faset ini tinggi berarti ia merasa bahwa hidupnya baik. (2) Hidup teratur (Order) menunjukkan bahwa adanya well-organized, rapi, mereka meletakkan segala sesuatu pada tempatnya pada skor yang tinggi pada faset ini. (3) Patuh terhadap peraturan (Dutifulness) yang menunjukkan ketaatan pada prinsip-prinsip etika dan sangat hati-hati pada nilai-nilai moral. (4) Mencapai prestasi (Achievement striving) mengungkapkan tingkat aspirasi tinggi dan bekerja keras untuk mencapai tujuan mereka. Mereka tekun dan bertujuan, dan punya keyakinan bahwa ia dapat mengarahkan hidupnya. (5) Memiliki disiplin diri (Self-discipline) menunjukkan kemampuan untuk memulai tugas dan mengerjakan tanpa kejemuan dan gangguan lain. Fase ini menunjukkan adanya kemampuan untuk memotivasi diri untuk menyelesaikan tugas. (6) Melakukan pertimbangan (Deliberation) menunjukkan adanya kecenderungan untuk berpikir sungguhsungguh sebelum bertindak.

\section{Kinerja Pegawai}

Secara etimologi, kinerja berasal dari kata prestasi kerja (performance). Sebagaimana dikemukakan oleh Mangkunegara, (2017) bahwa istilah kinerja berasal dari kota job performance atau actual performance (prestasi kerja atau prestasi sesungguhnya yang dicapai seseorang) yaitu hasil kerja secara kualitas dan kuantitas yang dicapai oleh seorang pegawai dalam melaksanakan tugasnya sesuai dengan tanggung jawab yang diberikan kepadanya.

Menurut Gibson (2008 : 70), kinerja (performance) adalah hasil yang diinginkan dari perilaku. Dan kinerja individu adalah dasar kinerja organisasi. Sedangkan menurut Murdijanto (2001:29) menyatakan bahwa kinerja adalah hasil kerja yang dapat dicapai oleh seseorang atau kelompok orang dalam suatu organisasi sesuai dengan wewenang dan tanggung jawab masinemasing dalam rangka upaya mencapai tujuan oreanisasi bersangkutan secara legal, tidak melanggar hukum dan sesuai dengan moral maupun etika.

Yuwalliatin \& Sitty (2006) mengatakan bahwa kinerja diukur dengan instrumen yang dikembangkan dalam studi yang tergabung dalam ukuran kinerja secara umum kemudian diterjemahkan kedalam penelitian perilaku secara mendasar, meliputi :
a. Kuantitas kerja
b. Kualitas kerja
c. Pengetahuan tentang pekerjaan
d. Pendapat atau pernyataan yang disampaikan.
e. Perencanaan kegiatan 
Indikator kinerja karyawan digunakan sebagai indikator yang mengukur kinerja karyawan secara individual. Menurut Robbins (2006) terdapat 6 indikator yang dapat digunakan untuk mengukur kinerja karyawan, antara lain:

a. Mutu

Mutu kinerja karyawan diukur dari kualitas dan kesempurnaan dari tugas terhadap keahlian karyawan. Indikator ini sangat penting untuk suatu kemajuan atau kemunduran posisi suatu perusahaan atau organisasi

b. Kuantitas

Kuantitas merupakan jumlah kinerja yang dihasilkan oleh seorang karyawan. Jumlah kinerja dapat diukur sesuai dengan target ketika perencanaan deskripsi kerja. Sehingga pengukuran kuantitas kinerja akan lebih mudah dilakukan oleh pengelola perusahaan atau organisasi.

c. Ketepatan Waktu

Ketepatan waktu merupakan hal penting dalam kinerja. Indikator yang satu ini menjadi kunci yang penting dari ketepatan sebuah target.

d. Efektivitas Penggunaan Sumber Daya

Efektivitas penggunaan sumber daya sebagai indikator kinerja karyawan. Semakin karyawan efektif dalam menggunakan sumber daya seperti tenaga, uang, teknologi, dan bahan baku kemudian kinerja yang dihasilkan semakin baik maka kinerja karyawan tersebut dapat dikatakan baik. Efektivitas penggunaan sumber daya sangat berpengaruh terutama dalam mengoptimalkan sumber daya yang ada serta menghasilkan kinerja yang maksimal demi pencapaian target perusahaan atau organisasi.

e. Mandiri

Kemandirian juga ternyata penting dalam penilaian indikator kinerja. Karyawan yang mandiri tidak akan merepotkan rekan kerjanya. Namun meski kemandirian penting, tuntutan akan kemampuan bekerja dalam tim juga tidak boleh diabaikan. Sehingga faktor yang satu ini dapat dijadikan salah satu indikator untuk mengukur kinerja karyawan.

f. Berkomitmen

Komitmen sangat menentukan motivasi karyawan untuk melakukan pekerjaannya. Karyawan yang berkomitmen cenderung akan lebih termotivasi dan memiliki rasa bertanggung jawab untuk mengerjakan pekerjaannya dengan baik. 


\section{KERANGKA PEMIKIRAN}

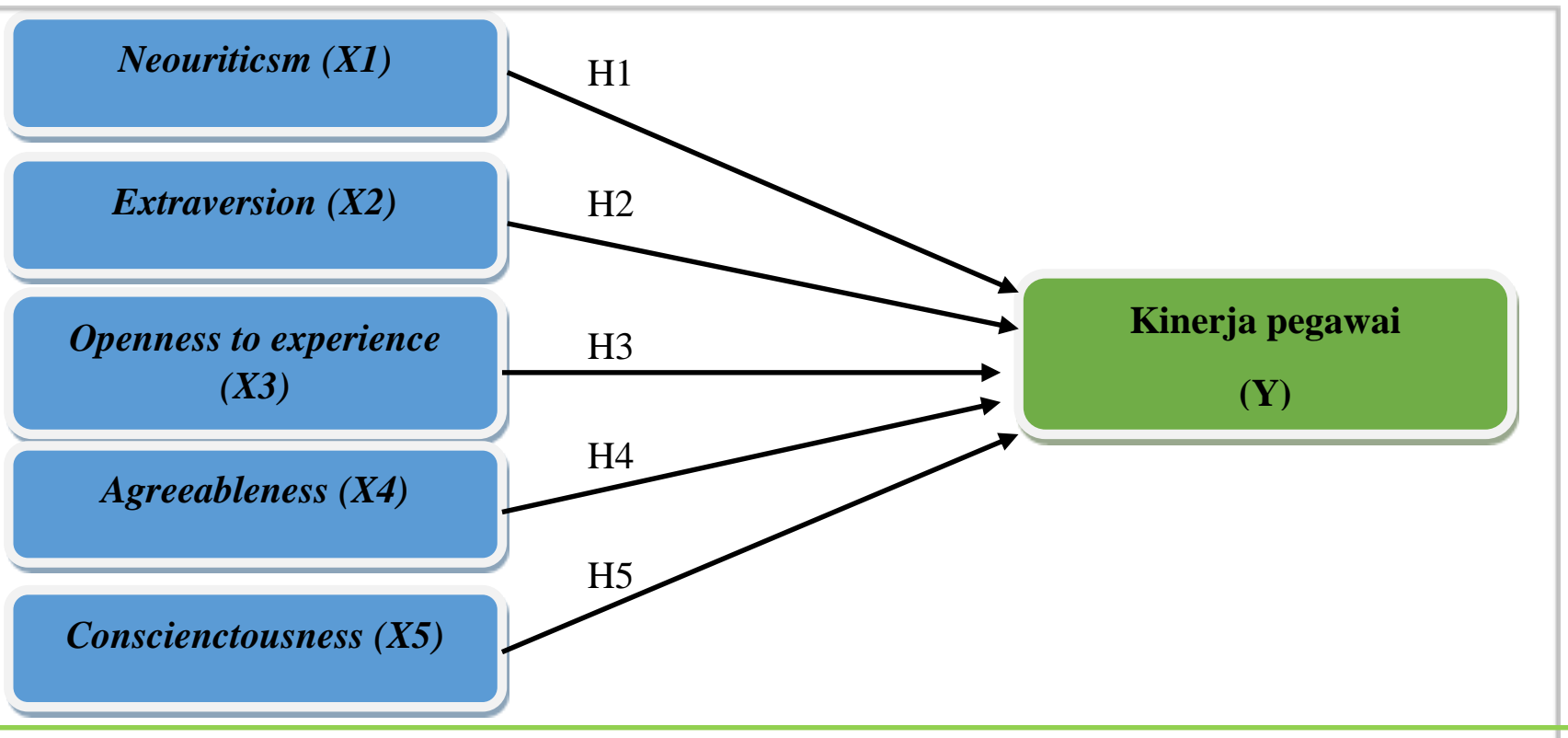

\section{HIPOTESIS PENELITIAN}

\section{Gambar 1. Kerangka Berpikir}

H1 : Neouriticsm berpengaruh positif dan signifikan terhadap kinerja pegawai.

$\mathrm{H} 2$ : Extraversion berpengaruh positif dan signifikan terhadap kinerja pegawai

H3 : Openness to experience berpengaruh positif dan signifikan terhadap kinerja pegawai

H4 : Agreeableness berpengaruh positif dan signifikan terhadap kinerja pegawai

H5 : Conscienctousness berpengaruh positif dan signifikan terhadap kinerja pegawai

\section{DAFTAR RUJUKAN}

A.A. Anwar Prabu Mangkunegara. 2017. Manajemen Sumber Daya Manusia Perusahaan, Bandung : Remaja Rosdakarya.

Artha, W. I., \& Supriyadi. (2013). Hubungan Antara Kecerdasan Emosi dan Self Efficacy dalam Pemecahan Masalah Penyesuaian Diri Remaja Awal. Psikologi Udayana, I(1), 190-202.

Devito, Joseph A. 2011. Komunikasi Antar Manusia. Pamulang-Tangerang Selatan: Karisma Publishing Group

Gibson, M. 2008. Manajemen Sumber Daya Manusia. Cetakan ke dua. Jakarta: Erlangga.

Ghufron \& Risnawita. (2011). Teori-Teori Psikologi. Yogyakarta: Ar-Ruzz Madia.

Handoko, T. Hani. 2014. Manajemen Personalia dan Sumber Daya Manusia. BPFE, Yogyakarta. Indra D, Wulandari Y. Prinsip-prinsip Dasar Ahli Gizi. Jakarta Timuir: Dunia Cerdas; 2013. Rachmawati, Ike Kusdyah. 2008. Manajemen Sumber Daya Manusia. Yogyakarta: ANDI. Murdiyanto, A. 2012. Analisis Pengaruh Motivasi Dan Lingkungan Kerja Terhadap Kinerja Karyawan Motor Hepy Cabang Jawa Tengah. Jurnal, Vol 9, edisi 1, hal 12- 28. 
John, O. P, \& Srivastava, S. (1999). The Big Five Trait Taxonomy: History, Measurement, and Theoretical Perspectives . In L. A. Pervin, \& O. P. John (Eds.), Handbook of Personality: Theory and Research 2nd ed., 102 - 138. New York: Guilford.

Montolalu, dkk (2007). Bermain dan Permainan Anak. Jakarta : Universitas TerbukaS.P,Hasibuan, Malayu. 2013. Manajemen Sumber Daya Manusia. Jakarta: PT Bumi Aksara

Pervin, L. A., Cervone, D., dan John O.P. 2010. Psikologi Kepribadian : Teori dan Penelitian. Jakarta : Kencana. (edisi kesembilan)

Robbins, Stephen P., 1998, perilaku Organisasi, edisi bahasa Indonesia Cetakan ke 2, Jakarta, Prenhallindo.

Robbins, P. Stephen. (2006). Perilaku Organisasi. Edisi Sepuluh. Diterjemahkan oleh: Drs. Benyamin Molan. Erlangga, Jakarta

Sitty Yuwalliatin. 2006. Pengaruh Budaya Organisasi, Motivasi dan Komitmen Terhadap Kinerja Serta Pengaruhnya Terhadap Keunggulan Kompetitif Dosen Unissula Semarang. Jurnal Ekonomi dan Bisnis, Vol. 7 No. 2, Juli, p. 241-256.

Stephen P. Robbins, 1996.Perilaku Organisasi, Konsep, Kontroversi danAplikasi. Alih Bahasa : Hadyana Pujaatmaka. Edisi Keenam. Penerbit PT.Bhuana Ilmu Populer, Jakarta.

Widiastuti, (2011) Tes dan Pengukuran Olahraga. Jakarta: PT Bumi Timur Jaya. 